\title{
Bat Species Richness and Their Distribution in Pokhara Valley of Nepal.
}

\section{Hari Adhikari ${ }^{1}$}

\begin{abstract}
Compared with the numerous studies on Chiroptera in other countries only little information has been published on Nepalese bats. Status of bats in Nepal has not been identified and even not given more interest by the government body which is devoted to wildlife managements itself. In Nepal, out of 51 species recorded by CAMP in 2002, 2 are critically endangered, 1 endangered and 5 are vulnerable. Pokhara valley is the city of caves. Some by products reports appear on bats of As Pokhara valley out of which 11 species belongs to Least concerned (LC), 5 Not threatened (NT), 1 Critically endangered (CR), 1 Endangered (EN) which is $35.29 \%$ of bats species of Nepal. Few roosting sites of bats have been identified in Pokhara valley. These sites are distributed in the Lekhnath municipality, Pokhara sub-metropolitan city, Bhalam VDC, Armala VDC and Hemja VDC. Among the 12 roosting sites, two are tree roosts and the remaining ten are cave roosts.
\end{abstract}

Key Words: Chiroptera, Roosts, Status, Species, Sites, Pokhara

Scientists often refer to bats as Chiropterans. Globally, the Order Chiroptera (from the Latin "hand wing") is currently composed of 17 families, about 177 genera and about 1116 species (Wilson and Reeder,2005). Chiropterans are subdivided into two main groups (suborders): Megachiroptera (the Old World Fruit Bats or Flying Foxes) and Microchiroptera (any bat that isn't a Fruit bat).

Megachiroptera have some 186 species of Fruit bat, grouped into 42 genera in a single family, the Pteropodidae. The larger, or megabats, generally have big eyes and small ears, and foxlike faces. These species of bats feed on fruit, nectar, or pollen. They live in the tropics and usually do not hibernate.

The Microchiroptera is the larger of the suborders, consisting of the remaining 16 families, 135 genera and somewhere in the region of 930 species. Of the Microchiropterans, the most diverse family is probably the Phyllostomidae (the New World Leaf-nosed Bats), with 49 genera, and the largest family the Vespertilionidae (Vesper or "Evening" Bats), with an impressive 308 species divided into 34 genera. They are smaller, insect eaters and rely more on their ears than their eyes to find food. Some bats can eat as many as 600 mosquitoes per hour. Many of them must hibernate in the winter when insects are not available. (Source: http://www.wildlifeonline.me.uk/bats.html)

\footnotetext{
Coordinator, Bat Friends, IOF Pokhara, harisubash2002@yahoo.com
} 
Bats are mammals and warm blooded, just like us. They have fur, give birth to live young who feed on their mother's milk and are generally shy and gentle. Bat consists of about 20 percent of all the mammal species in the world. Bats are the only true flying mammals in the world. They range in size of a bumblebee, Kitti's Hog Nosed Bat (Crassesonycteris thonglongyai), which is recorded from Thailand and its adjoining areas of Southeast Asia and weighs less than a penny (about

\begin{tabular}{|l|l|}
\hline Kingdom & Animalia \\
\hline Phylum & Chordata \\
\hline Class & Mammalia \\
\hline Group & Eutheria \\
\hline Order & Chiroptera \\
\hline Sub-orders & Megachiroptera \\
\hline & Microchiroptera \\
\hline
\end{tabular}
2-3.2 gm) (Francis,2008), to flying foxes in Asia

(Indonesia) with nearly six-feet of wingspan and weighs around two pounds. Bats can be found throughout the world except in certain oceanic islands, the Arctic and Antarctic. (www.batcon.org)

Bats are nocturnal, which means they are mostly active at night and sleep during the day. They sleep upside down by hanging onto the tops of caves, trees, or buildings with toe claws. During the night bats search for food, using echolocation to find it. They send out hundreds of highpitched sounds per second. By reading the echoes that return to them from nearby objects they can "see" what is around them.

\section{History and Status of Bats in Nepal}

As compared with the numerous studies on Chiroptera in other countries relatively only little information has been published on Nepalese bats. Exploration of the mammal's fauna started in the middle of the last century which was restricted to the Katmandu Valley which at that time was the only place available to Westerners. Although British resident Brian Hodgson yielded several new species of the bats among many other vertebrates from this territory. Due to silence policy of the Government at that time, Nepalese borders still remained closed to foreigners this promising start was not continued. After the opening to the outside world from the 1950's onward, the incredible orographic, botanical and zoological diversity of Nepal attracted several scientific expedition starting with North American and German Scientists. But for a long time new data on the Chiroptera fauna came only as by- products of other Zoological investigations or of other mammal's surveys. The latter researcher mainly concentrated on the key stone species generally mega fauna. Therefore our present knowledge on bats is very incomplete. (Adhikari, 2007)

According to South Asian Chiroptera Conservation Assessment and Management Plan (C.A.M.P.) Workshop Report, 2002 Nepal consists of 51 species of bats which are as follows: 5 data deficient, 5 Vulnerable, 20 Not threatened, 17 Least concerned, 2 Critically endangered, 1 Endangered, 1 Status unknown. But few other researchers compile few more bats in Nepal.

\section{Pokhara valley}

Pokhara valley is located in Kaski district of western region of Nepal. The precise geographical location of the valley is between $28^{\circ} 24^{\prime}$ to $28^{\circ} 4^{\prime} \mathrm{N}$ and $83^{\circ} 99^{\prime}$ to $84^{\circ} 65^{\prime} \mathrm{E}$. The average height 
of the Pokhara valley above the sea level ranges from $730 \mathrm{~m}$ to $1030 \mathrm{~m}$. The main precipitation here occurs in the form of rainfall. The climate is sub-tropical but due to the elevation, the temperatures are moderate: the summer temperatures average between $25-35^{\circ} \mathrm{C}$, in winter around $5-15^{\circ} \mathrm{C}$. Various researches have been done in Pokhara during different time events. Some information on Bats has been published as a by product of some other research.

\section{Bat species richness in Pokhara valley based on research and secondary data collection}

No specific research on Bats of Pokhara has been done except Phuyal, (2005), Acharya, (2006).

Csorba (in 1999) reported Rhinolophus macrotis and Hipposideros armiger from Batule Chour, $8 \mathrm{Km}$ North of Pokhara. Tej Kumar Shrestha reported Kerivoula picta (in 2000) and Rhinolophus subbadius in his publication "Mammals of Nepal" (1997).

Sujas has identified some 12 bat roosting sites. These sites are distributed in the Lekhnath municipality, Pokhara sub-metropolitan city, Bhalam VDC, Armala VDC and Hemja VDC. Among the 12 roosting sites, two are tree roosts and the remaining ten are cave roosts. All of the roosts identified are situated in and around urban areas. Three of the caves (Gupteshwor Cave, Bat Cave and Mahendra Cave) are already known roosts. The remaining caves and tree roosts were documented for the first time. Roosting sites and their GPS coordinate in Pokhara Valley are listed below:-

\begin{tabular}{|c|c|c|c|c|c|}
\hline S. & Name of the & Location & GPS & cation & Remarks \\
\hline N. & Roost & & Latitude & Longitude & \\
\hline 1 & Sita Cave & Lekhnath -14 & $28^{\circ} 14^{\prime} 50^{\prime \prime}$ & $84019 "$ & Accessible cave roost \\
\hline 2 & Pandit Chowk & Pokhara-18 & $28^{\circ} 14^{\prime} 50^{\prime \prime}$ & $84^{\circ} 0^{\prime} 14^{\prime \prime}$ & Accessible tree roost \\
\hline 3 & Radhakrishna tole & Pokhara-18 & $28^{\circ} 15^{\prime} 31^{\prime \prime}$ & $83^{\circ} 57^{\prime} 6^{\prime \prime}$ & Accessible tree roost \\
\hline 4 & Radhe radhe Cave & Pokhara-15 & $28^{\circ} 8^{\prime} 30^{\prime \prime}$ & $83^{\circ} 5^{\prime} 54^{\prime \prime}$ & Inaccessible cave roost \\
\hline 5 & Buddha C ave & Pokhara-9 & $28^{\circ} 10^{\prime} 45^{\prime \prime}$ & $84^{\circ} 0^{\prime} 52^{\prime \prime}$ & Inaccessible cave roost \\
\hline 6 & Gupteshwor C ave & Pokhara -17 & $28^{\circ} 10^{\prime} 56^{\prime \prime}$ & $84^{\circ} 0^{\prime} 40^{\prime \prime}$ & Accessible cave roost \\
\hline 7 & Peace Cave & Hemja- 2 & $28^{\circ} 11^{\prime} 22^{\prime \prime}$ & $83^{\circ} 57^{\prime} 32^{\prime \prime}$ & Accessible cave roost \\
\hline 8 & Bat Cave & Pokhara-16 & $28^{\circ} 15^{\prime} 48^{\prime \prime}$ & $83^{\circ} 59^{\prime} 32^{\prime \prime}$ & Accessible cave roost \\
\hline 9 & Mahendra C ave & Pokhara-16 & $28^{\circ} 16^{\prime} 3^{\prime \prime}$ & $83^{\circ} 58^{\prime} 36^{\prime \prime}$ & Accessible cave roost \\
\hline 10 & Crazy Cave & Armala- 6 & $28^{\circ} 16^{\prime} 19^{\prime \prime}$ & $83^{\circ} 58^{\prime} 51^{\prime \prime}$ & Accessible cave roost \\
\hline 11 & Putali Cave & Bhalam -2 & $28^{\circ} 12^{\prime} 37^{\prime \prime}$ & $83^{\circ} 59^{\prime} 33$ & Accessible cave roost \\
\hline 12 & Birendra Cave & Bhalatn -2 & $28^{\circ} 10^{\prime} 44^{\prime \prime}$ & $83^{\circ} 59^{\prime} 33$ & Accessible cave roost \\
\hline
\end{tabular}

Source: Sujas, 2005

During his study eleven species were recorded from Pokhara Valley. These bats belong to four families, four sub-families, and nine genera. Of the bats identified, three species are fruit bats from the Family Pteropodidae. The remaining eight species are insectivorous bats, belonging to the following families: Megadermatidae (1), Rhinolophidae (2), Pteropodidae (3) and Vespertilionidae (5). Bat species recorded by Sujas are Megaderma lyra, Cynopterus 
sphinx, Pteropus giganteus, Rousettus leschenaulti, Hipposideros pomona, Rhinolophus pusillus, Myotis formosus, Myotis muricola, Myotis siligorensis, Pipistrellus javanicus and Scotophilus heathii.

Dr. LuisRuedas, (Fulbright Scholar to Kathmandu University from Portland State University), identified Hipposideros (Rhinolophus) armiger and Rhinolophus macrotis during "Training and interaction program on Bats"on 3-5 September, 2006. Pteropus giganteus were found foraging at the forest which is reported formally by the residents of Chhinedada of Pokhara Valley. Total 6 species were recorded from Banpale forest situated within the premises of IOF using an ultra sound detector (http://batfriends.tripod.com). Acharya during his master dessertation submition to the Central Department of Zoology, Tribhuvan University reported presence of Rhinolophus armiger and Rhinolophus pussilus in Bat Cave. (Acharya, 2006). Other records are found from Dr. Paul A. Racey (Chair, IUCN SSC Chiroptera specialist Group) and Dr. Sripathi Kandula (Scientific chair of CCINSA from Madurai Kamaraj University) during "Field Techniques for Research and Conservation of Volant and Non Volant Small Mammals" at Pokhara at Institute of Forestry. They identified Rhinolophus affinis, Rousettus leschenaulti, Hipposideros armiger, Miniopterus spvecies in World peace cave and Rhinolophus affinis and Hipposideros armiger in Birendra cave and Pipistrellus coromandra/ javanicus at Institute of Forestry, Banpale forest. Paul also recommended that there could be 90 species of bats in Nepal instead of the few from existing reports. The fauna of bats of Nepal is improperly known. (Daniel, 2007)

Bates and Harrison, 1997 and CAMP report 2002 reported Rhinolophus macrotis, Rhinolophus pusillus, Rhinolophus subbadius, Hipposideros armiger, Hipposideros pomona, Miniopterus pusillus, Kerivoula picta from Pokhara Valley. \{Bates, (1997); Molur, (2002)\}

Adhikari reported presence of Rhinolophus armiger and Rhinolophus pussilus from Bat Cave, at Batulechaur, during one day training program organized at Bat Cave. (Adhikari et al., 2008)

\section{Conclusion}

Pokhara is a potential habitat for bats of Nepal. There is need of extensive survey of bats in Pokhara Valley. This city can also be developed as potential tourist site for bat watching as large number of caves exists in this valley. A total of 18 species of bats are reported by different author through different publication. These bats belong to 5 families and 11 genera. Of the bats identified, 3 species are fruit bats from the Family Pteropodidae. The remaining 15 species are insectivorous bats, belonging to the following families: Megadermatidae (1), Rhinolophidae (5), Hipposideridae (1) and Vespertilionidae (8). They are listed below of which 11 species belongs to Least concerned (LC), 5 Not threatened (NT), 1 critically endangered (CR), 1 Endangered (EN). 


\begin{tabular}{|c|c|c|c|c|c|}
\hline $\begin{array}{l}\text { S. } \\
\text { N. }\end{array}$ & Family & Genus & Common Name & Scientific Name & $\begin{array}{l}\text { Red } \\
\text { List }\end{array}$ \\
\hline 1 & Megadermatidae & Megaderma & $\begin{array}{l}\text { Greater False-vampire } \\
\text { bat }\end{array}$ & Megadema lyra & LC \\
\hline 2 & Pteropodidae & Cynopterus & Short-nosed Fruit Bat & $\begin{array}{l}\text { Cynopterus } \\
\text { sphinx }\end{array}$ & LC \\
\hline 3 & Pteropodidae & Pteropus & Indian flying fox & $\begin{array}{l}\text { Pteropus } \\
\text { giganteus }\end{array}$ & LC \\
\hline 4 & Pteropodidae & Rousettus & Fulvous Fruit Bat & $\begin{array}{l}\text { Rousettus } \\
\text { leschenoult }\end{array}$ & N T \\
\hline 5 & Rhinolophidae & & $\begin{array}{l}\text { Andersen's Leaf-nosed } \\
\text { Bat }\end{array}$ & $\begin{array}{l}\text { Hipposideros } \\
\text { pomona }\end{array}$ & N T \\
\hline 6 & Rhinolophidae & Rhinolophus & Least Horseshoe Bat & $\begin{array}{l}\text { Rhimolophus } \\
\text { pusillus }\end{array}$ & $\mathrm{LC}$ \\
\hline 7 & Rhinolophidae & Rhinolophus & $\begin{array}{l}\text { Intermediate Horse- } \\
\text { shoe Bat }\end{array}$ & $\begin{array}{l}\text { Rhimolophus } \\
\text { affinis }\end{array}$ & $\mathrm{LC}$ \\
\hline 8 & Rhinolophidae & Rhinolophus & $\begin{array}{l}\text { Big-eared Horse-shoe } \\
\text { Bat }\end{array}$ & $\begin{array}{l}\text { Rhimolophus } \\
\text { macrotis }\end{array}$ & N T \\
\hline 9 & Rhinolophidae & Rhinolophus & $\begin{array}{l}\text { Chestnut Horseshoe } \\
\text { Bat }\end{array}$ & $\begin{array}{l}\text { Rhimolophus } \\
\text { subbadius }\end{array}$ & EN \\
\hline 10 & Vespertilionidae & Myotis & Hodgson's Bat & Myotis formosus & N T \\
\hline 11 & Vespertilionidae & Myotis & $\begin{array}{l}\text { Nepalese Whiskered } \\
\text { Bat }\end{array}$ & Myotis muricola & L C \\
\hline 12 & Vespertilionidae & Myotis & $\begin{array}{l}\text { Himalayan Whiskered } \\
\text { Bat }\end{array}$ & $\begin{array}{l}\text { Myotis } \\
\text { siligorensis }\end{array}$ & N T \\
\hline 13 & Vespertilionidae & Pipistrellus & Javan Pipistrile & $\begin{array}{l}\text { Pipistrellus } \\
\text { javanicus }\end{array}$ & $\mathrm{LC}$ \\
\hline 14 & Vespertilionidae & Scotophilus & $\begin{array}{l}\text { Asiatic Greater Yellow } \\
\text { House Bat }\end{array}$ & $\begin{array}{l}\text { Scotophilus } \\
\text { heathii }\end{array}$ & L C \\
\hline 15 & Vespertilionidae & Miniopterus & $\begin{array}{l}\text { Nicobar Long-fingered } \\
\text { Bat }\end{array}$ & $\begin{array}{l}\text { Miniopterus } \\
\text { pusillus }\end{array}$ & CR \\
\hline 16 & Vespertilionidae & Pipistrellus & Coromandel Pipistrelle & $\begin{array}{l}\text { Pipistrellus } \\
\text { coromandra }\end{array}$ & $\mathrm{LC}$ \\
\hline 17 & Vespertilionidae & Kerivoula & Painted Bat & Keriwoula picta & LC \\
\hline 18 & Hipposideridae & Hipposideros & $\begin{array}{l}\text { Great Himalayan Leaf- } \\
\text { nosed Bat }\end{array}$ & $\begin{array}{l}\text { Hipposideros } \\
\text { ormiger }\end{array}$ & $\mathrm{LC}$ \\
\hline
\end{tabular}

\section{References:}

Acharya, Puspa Raj (2006). Distribution of roosting and survival threats of bat in Pokhara valley with reference to species and population survey at Chamere Gupha; A dessertation submitted to the Central Department of Zoology, Tribhuvan University, Kirtipur, Kathmandu.

Adhikari, Hari (2007); "History, Importance, Status of Bats and their threats in Nepal", Prabhat 2007, Vol 1, Publication 14, Year 15. ANNFSU, IOF 
Adhikari, Hari and K.C. Mohan, 2008. One day training programme on bat, organized at Bat Cave, Pokhara, Nepal. pp. 21-22, Bat Net Newsletter, Newsletter of the Chiroptera Conservation and information Network of South Asia CCINSA and the IUCN SSC Chiroptera Specialist Group of South Asia (CSGSA), Volume 9, Number 1, Jan - July 2008.

Bates, Paul JJ and Harrison, David L (1997). Bats of Indian subcontinent Harrison zoological Mueseum Publication.

Charles M. Franchis,(2008). Mammals of Thailand and Southeast Asia. Asia Books Co. Ltd.

Daniel, B. A., 2007.Training in Field Techniques for Survey and Conservation of Bats, Nepal, pp. 5-9. Bat Net Newsletter, Newsletter of the Chiroptera Conservation and information Network of South Asia CCINSA and the IUCN SSC Chiroptera Specialist Group of South Asia (CSGSA), Volume 8, Number 1-2, Jan - Dec 2007.

G. Csorba, S.V Kruskop and A.V Borissenko (1999). Rescent records of bats (Chiroptera) from Nepal, with remarks on their natural history.Mammalia, t.63, $\mathrm{n}^{\circ} 1$, pp 6178.Department of Zoology, Hungarian Natural Hisory Museum, Zoological Museum of Moscow State University.

Phuyal, Sujal P. (2005). Survey of bats of Pokhara Valley, Nepal. Report submitted to Bat Conservation International, Austin, Texas, USA. August 2005.

S. Molur, G. Marimuthu, C.Srinivasulu, S. Mistry, A.M. Hutson, P.J.J. Bates, S.Walker, K. Padma Priya and A. R. Binu Priya (Editors) (2002). Status of South Asian Chiroptera: Conservation Assessment and Management Plan(C.A.M.P) Workshop Report, 2002. Zoo Outreach Organization, CBSG South Asia and WILD, Coimbatore, India, viii+141pp+CD-Rom.

Shrestha, T.K. (1997). Mammals of Nepal. Shrestha publishers, Kathmandu.371 pp.

Wilson DE and DM Reeder (eds.).2005. Mammal Species of the World ( $3^{\text {rd }}$ edition) Baltimore Maryland: John Hopkins University Press2,142p

http://www.wildlifeonline.me.uk/bats.html

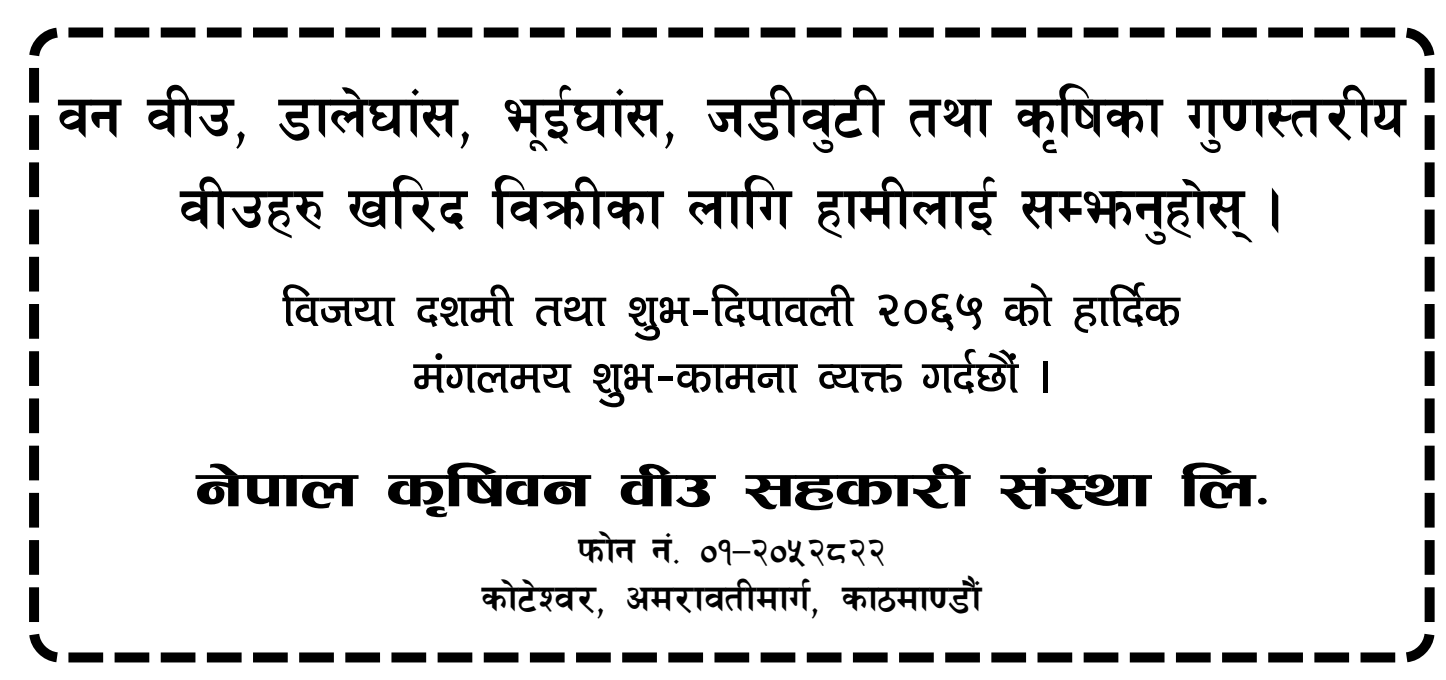

